\title{
Principal Conditions and Geochemical Trends in Formation of High-grade Bauxite Deposits, Republic of Guinea
}

\author{
Vladimir Mamedov ${ }^{1, *}$, Alexey Chausov $^{2}$, and Marina Makarova ${ }^{1}$ \\ ${ }^{1}$ Lomonosov Moscow State University, Moscow, Russia, frolikovam@gmail.com \\ ${ }^{2}$ GEOPROSPECTS LTD, Sangaredi, Republic of Guinea, info@ geoprospects.org
}

\begin{abstract}
Conditions and principal geochemical trends in the formation of bauxite-bearing lateritic mantles are considered on the example of Fouta Djalon-Mandingo Bauxite-bearing Province as the best natural model. Input and output dynamics of petrogenic components was calculated on the isovolumetric base and the obtained data were used to interpret the zoned structure of weathered profile as resulting from its hydrogeological and gas regimes. Although $\mathrm{Al}$ separates from $\mathrm{Fe}$ in the formation of bauxite horizon, three-valence iron is a typomorphic element of the lateritic landscape as a whole, with $50 \% \mathrm{Al}$ leaching from lateritic mantle.
\end{abstract}

\section{Introduction}

The Fouta Djalon-Mandingo bauxite-bearing province occupying an area only of some $100000 \mathrm{~km}^{2}$ is the largest in the world, as holding $47 \mathrm{Bt}$ bauxites, about $50 \%$ the worlds bauxite resources, calculated at $\mathrm{Al}_{2} \mathrm{O}_{3}$ cutoff grade $40 \%$. Therefore, it may and should be considered as a natural model of the environmental conditions and geochemical trends most favorable for large-scale formation of bauxite-bearing lateritic mantles (LM).

The environmental conditions in the province are (1) widespread silty mudstones and dolerites representing aluminosilicate parent rock chemically favorable for bauxitization, (2) long, at least from Late Cretaceous, exposure to tropical climate, and (3) mainly ascending pulsing regional geodynamics as a formation factor of favorable geomorphological conditions (steplike fragments of heterochronous planation surfaces called bowes), as well as a factor of hydrodynamical, hydrochemical, and biochemical environments of the lateritic weathering profile.

By now, the qualitative environmental characteristics mentioned as favorable have got quantitatively estimated.

For example, the overwhelming majority of researchers have agreed that the most favorable climate is that with a high annual air temperature (over $20^{\circ} \mathrm{C}$ ) and abundant rainfall (over 1100-1300 mm/year), classified as monsoon-type, typical of the landscapeclimatic zones of wet savanna. They also agreed that the favorable environment appeared only after a partition of pediplains and essential downcutting - a descent of local base level.

\footnotetext{
*Corresponding author: frolikovam@gmail.com
} 
Remained questions have concerned the estimation of favorableness degree of parent rock on their chemical, mineralogical, and petrographic characteristics. Stress is mainly put on abundance of the silica bound in quartz. According to our data, this index role is essentially negative only in case of coarse (over 1-3 mm) grains of especially sedimentary (naturally graded, firm) quartz. However, lateritic bauxites readily form after silty mudstones and fine sandstones with quartz grains measuring less 0.1-0.2 mm, with quartz abundance of $50 \%$. According to our data, the major negative chemical factor from parent rock is their high iron, namely, their low iron module $\left(\mathrm{Al}_{2} \mathrm{O}_{3} / \mathrm{Fe}_{2} \mathrm{O}_{3}\right)$, especially when it is less 1.5 .

\section{Results and Discussion}

To study general geochemical trends of an autonomous lateritic landscape one should identify a typomorphic chemical element. Computations were made for the bauxite-bearing region of Kogon-Tomine interfluve occupying over $4500 \mathrm{~km}^{2}$ and holding about $11 \mathrm{Bt}$ bauxite, the greatest bauxite and aluminum concentration in the World!

Summarized in Table 1 are the estimates based on results of over 6000 tests for the absolute concentration $\left(\mathrm{kg} / \mathrm{m}^{3}\right)$ of petrogenic components in the averaged parent rock (dolerites of $33 \%$ and Devonian and Silurian silty mudstones of $64 \%$ ), with details of zones-horizons of the lateritic mantle (LM), as well as with generalizations for the bauxitebearing lateritic mantle as a whole and the properly lateritic mantle as a whole, including those bauxite-bearing and those bauxite-free (outside of bauxite deposits). For each zonehorizon, concentration coefficient $(\mathrm{Cc})$ of each component is calculated as the ratio of its average concentration to its concentration in parent rock. Cc $>1$ shows absolute accumulation (input) of the matter; $\mathrm{Cc}<1$, its loss.

What are the important conclusions to be made on these data?

First of all, typical of formation of the whole LM that occurs above kaolinite clays dominating at the surface (first 9 to $11 \mathrm{~m}$ ) of relief is the highest absolute accumulation of iron: $\mathrm{Cc}$ is almost 4. For such conditions it is $\mathrm{Fe}^{3+}$ that should be considered as the typomorphic element of lateritic landscape.

Iron of LM of the area originates only from parent rock: there is no any other source of iron. To get $\mathrm{Cc}=4$ would need to mobilize iron for each $\mathrm{LM} \mathrm{m}^{3}$ from $4 \mathrm{~m}^{3}$ of parent rock. And this is the minimum, the case of $100 \%$ iron remaining in the mantle, which is improbable.

And what about alumina? Its $\mathrm{Cc}$ is about 2, i.e., each $\mathrm{m}^{3}$ of the mantle contains $\mathrm{Al}_{2} \mathrm{O}_{3}$ only from $2 \mathrm{~m}^{3}$ of parent rock. Note however, that alteration of $4 \mathrm{~m}^{3}$ of parent rock is needed to get the real concentration of iron in the mantle. Therefore, aluminum from each 2 $\mathrm{m}^{3}$ of those $4 \mathrm{~m}^{3}$ altered was leached out of LM. The objective data based on the largescale rather than any local example rule out the thesis of maximum aluminum inertness in LM.

Let us look at changes in the essence and trend of geochemical processes up-section of the weathering mantle.

When clay horizon is forming, absolute concentrations of aluminum and iron remain practically changeless, whereas silica shows a considerable loss and $80 \% \mathrm{RO}$ and $\mathrm{R}_{2} \mathrm{O}$ get mobilized. Therefore, the clay horizon may be considered as a residue of the chemical weathering. Note however, that the uppermost section of clayey horizon already demonstrates a considerable input of iron and a conspicuous input of alumina, with appearance of free alumina, on the background of continuing loss of silica. It is the section of clay horizon that periodically emerges above the permanently watered zone.

Note that the average $\mathrm{SiO}_{2}$ concentration in the ground water of bauxite-bearing $\mathrm{LM}$ is $1.4 \mathrm{mg} / \mathrm{L}$ [3]. Only in some samples collected at deep intervals of piesometric wells its 
concentration is up to $5.5 \mathrm{mg} / \mathrm{L}$. Confirmed are the conclusions that kaolinite is in equilibrium with a liquid phase with $\mathrm{SiO}_{2}$ over $5 \mathrm{mg} / \mathrm{L}$ [1] or over 2-3 mg/L [2].

Above the horizon of kaolinite clay there is the horizon of ferruginous laterite that spatially coincides with the hydrogeological zone of phreatic fluctuation in the rainy season. When compared with parent rock and clays on the average this zone shows the absolute accumulation of $\mathrm{Fe}_{2} \mathrm{O}_{3}$ over $500 \mathrm{~kg} / \mathrm{m}^{3}$ (!), with $\mathrm{Al}_{2} \mathrm{O}_{3}$ also accumulated up to 240 $\mathrm{kg} / \mathrm{m}^{3}$. Upsection of this zone with thickness of 2-6 m (3.3 m on the average) $\mathrm{SiO}_{2}$ loss increases to that practically complete, i.e., kaolinite degrades almost entirely to be replaced by $\mathrm{Al}$ and $\mathrm{Fe}$ oxides and hydroxides, which indicates the proper laterization. It is this horizon from where the proper LM profile starts upsection.

Total balance of matter shifts to input, and as a consequence, the rock volume weight increases from 1460 to $1900 \mathrm{~kg} / \mathrm{m}^{3}$. Such an intense $\mathrm{Fe}_{2} \mathrm{O}_{3}$ accumulation, the abundant $\mathrm{Fe}^{3+}$ precipitation, is a certain evidence for the active oxidizing geochemical barrier occurring there.

Higher in the profile there is the hydrogeological zone of infiltration and aeration. The water-rock system gets the gaseous component from the ground air existing above the ground water table (GWT) [4]. After each rain $\mathrm{CO}_{2}$ accumulates there. Its concentration above GWT reaches $12-14 \%$, whereas $\mathrm{O}_{2}$ concentration decreases to 4-6\%. Upsection, $\mathrm{CO}_{2}$ concentration decreases and $\mathrm{O}_{2}$ concentration increases to values typical of the earth atmosphere. Laterization products change in composition with the zoning of ground air. Above GWT ferruginous laterites get replaced by light bauxites that upsection give place to more ferruginous red bauxites (usually at depths less than 5-3 m) and frequently to highly ferruginous laterites forming cuirass.

When compared with rocks of the transition zone those of the bauxite horizon demonstrate a rather intense loss of $\mathrm{Fe}_{2} \mathrm{O}_{3}$ (almost $300 \mathrm{~kg} / \mathrm{m}^{3}$ ) and a rather intense input of $\mathrm{Al}_{2} \mathrm{O}_{3}$ (also almost $300 \mathrm{~kg} / \mathrm{m}^{3}$ ). This takes place in the zone of ground air pollution, i.e., in the zone poor in oxygen, which may be considered as a reason for the environment change from oxidizing to reducing (gley) in the subjacent transition zone. Any other interpretation can hardly explain the bulk loss of iron.

When compared with bauxites the superjacent cuirass horizon demonstrates a very intense absolute accumulation of $\mathrm{Fe}_{2} \mathrm{O}_{3}$ (almost $400 \mathrm{~kg} / \mathrm{m}^{3}$ ) and a less intense loss of $\mathrm{Al}_{2} \mathrm{O}_{3}$. The geochemical environment changes to oxidizing again. Therefore, in the proper LM there is no any horizon-zone, unlike the clay horizon, that could be considered as a pure residue of chemical weathering. From our viewpoint, these are results of the hypergene infiltration metasomatism that owing to the changes in geochemical environment caused by changing hydrogeological and gaseous regimes redistributed matter over the profile of weathering. Consequently, distinguishable are the zones and products of essentially ferruginous metasomatism (the transition zone and the cuirass at the profile foot and top, respectively) and essentially aluminous metasomatism (the bauxite zone).

Matter is transported over the LM profile with pore water rather than with ground or fracture water, and the pore water front gradually descends to GWT. Unlike the aluminum concentration in ground and surface waters of the region estimated at $0.009-0.075 \mathrm{mg} / \mathrm{L}$, its concentration in the pore water, diluted though it is by fracture water, is increased to 0.4$1.75 \mathrm{mg} / \mathrm{L}[3]$.

The evidence obtained on matter redistribution over the profile of weathering unambiguously indicate that there is the real geochemical environment arising in LM, favorable for the spatial separation between $\mathrm{Al}$ and $\mathrm{Fe}$, which results in formation of the bauxite horizon - bauxite deposits.

If the iron module in parent rock (Table 1) is estimated at 2 then its value keeps practically unchanged after the separation between $\mathrm{Al}$ and $\mathrm{Fe}(1.96)$, whereas its value in 
Table 1. The calculation of the concentration coefficients $(\mathrm{Cc})$ of the abundance of petrogenic components in the horizon zones of the lateritic weathering crust in relation to the parent rock.

\begin{tabular}{|c|c|c|c|c|c|c|c|c|c|c|c|c|}
\hline \multirow{2}{*}{\multicolumn{2}{|c|}{ Zone-horizon }} & \multirow{2}{*}{$\begin{array}{c}\text { Average } \\
\text { thickness, } \\
\text { m }\end{array}$} & \multirow{2}{*}{$\begin{array}{l}\text { Volume } \\
\text { weight, } \\
\mathrm{kg} / \mathrm{m}^{3}\end{array}$} & \multicolumn{5}{|c|}{$\begin{array}{l}\text { Abundance of petrogenic components, } \\
\mathrm{kg} / \mathrm{m}^{3}\end{array}$} & \multicolumn{4}{|c|}{ Cc relative to parent rock } \\
\hline & & & & $\mathrm{SiO}_{2}$ & $\mathrm{Al}_{2} \mathrm{O}_{3}$ & $\mathrm{Fe}_{2} \mathrm{O}_{3}$ & $\mathrm{RO}+\mathrm{RO}_{2}$ & LOI & $\mathrm{SiO}_{2}$ & $\mathrm{Al}_{2} \mathrm{O}_{3}$ & $\mathrm{Fe}_{2} \mathrm{O}_{3}$ & LOI \\
\hline \multirow{3}{*}{ 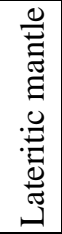 } & Ferruginous cuirass & 1,5 & 2300 & 72 & 827 & 846 & 2,7 & 481 & 0,05 & 2,09 & 4,28 & 3,57 \\
\hline & Bauxite & 8,1 & 2000 & 41 & 921 & 470 & 1,6 & 501 & 0,03 & 2,33 & 2,37 & 3,72 \\
\hline & Ferruginous laterite & 3,3 & 1900 & 90 & 644 & 742 & 2,9 & 369 & 0,06 & 1,63 & 3,75 & 2,74 \\
\hline \multicolumn{2}{|r|}{ Lateritic mantle as a whole, including } & 9,1 & 2000 & 59 & 730 & 734 & 2,1 & 416 & 0,04 & 1,84 & 3,71 & 3,09 \\
\hline \multicolumn{2}{|r|}{ bauxite-bearing } & 11,0 & 2000 & 54 & 859 & 550 & 2,0 & 473 & 0,04 & 2,17 & 2,78 & 3,51 \\
\hline \multicolumn{2}{|r|}{ bauxite-free } & 8,7 & 2000 & 60 & 706 & 770 & 2,1 & 405 & 0,08 & 1,74 & 3,80 & 2,58 \\
\hline \multirow{3}{*}{ 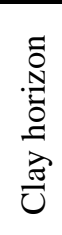 } & $\begin{array}{l}\text { Clay kaolinitic, red-colored, } \\
\text { ferruginous, the upper section }\end{array}$ & 1,5 & 1460 & 383 & 468 & 350 & 12 & 209 & 0,26 & 1,18 & 1,77 & 1,55 \\
\hline & $\begin{array}{l}\text { Clay pseudomorphous, light-colored, } \\
\text { kaolinitic or polymineral }\end{array}$ & 5,3 & 1605 & 791 & 387 & 175 & 63 & 148 & 0,53 & 0,98 & 0,88 & 1,09 \\
\hline & Pseudomorphous clay as a whole & 12,0 & 1590 & 730 & 405 & 203 & 55 & 157 & 0,49 & 1,02 & 1,02 & 1,17 \\
\hline \multicolumn{2}{|c|}{ Lateritic bauxite-bearing mantle as a whole } & 21,1 & 1770 & 484 & 535 & 409 & 35 & 259 & 0,33 & 1,35 & 2,06 & 1,92 \\
\hline \multicolumn{2}{|c|}{ Parent rock as a whole } & & 2510 & $\begin{array}{c}148 \\
4\end{array}$ & 396 & 198 & 256 & 135 & 1 & 1 & 1 & 1 \\
\hline
\end{tabular}


LM as a whole decreases to 1.5 and even 1 in the bauxite-free LM owing to more intense accumulation of iron.

On background of the bauxite formation epoch, in the province under consideration there was the environment favorable for spatial separation between aluminum and iron in the hypergenesis zone when the fluvial-lacustrine sediments of Sangaredi Group accumulated owing to iron loss under watered gley geochemical conditions [5]. This formed the low-ferruginous high-aluminous, with a very high iron module, new parent rock on the surface, and then premium-grade bauxites developed with its subsequent laterization. This is an example of separation between aluminum and iron before parent rock laterization.

And finally, after bauxite-bearing LMs get covered with lignite-bearing terrestrial deposits, also in the gley geochemical environment the bauxites get bleached (iron loss) and essentially improved to form high-alumina ore, for example, the bleached bauxite deposits of Guyana [6]. Note however, that this process is accompanied by resilification, i.e., on background of the bauxite degradation, its replacement by kaolines.

\section{Conclusion}

Principal geochemical trends revealed in the formation of bauxite-bearing mantles are the following:

- loss of $\mathrm{SiO}_{2}, \mathrm{RO}$, and $\mathrm{R}_{2} \mathrm{O}$ in the formation of clays occurs on the background of persistent initial amounts of aluminum and iron, which rules out their accumulation at upper levels by capillarity;

- change of redox conditions in LM profile causes the spatial separation between $\mathrm{Al}$ and $\mathrm{Fe}$ and, as a consequence, results in the formation of high-grade bauxites, in spite of the fact that absolute accumulation of iron in LM is generally twice as much as is that of aluminum;

- absolute accumulation of aluminum and iron in LM results from their mobilization at the upper level, in the soil that should be considered as the back zone of hypergene metasomatic column where all components become metastable.

\section{References}

1. Geological Evolution and Self-organization in Water-Rock System: Water-Rock System under Conditions of Hypergene Zone /Novosibirsk: SORAN, 2 (2007)

2. V.V. Zhukov, B.A.Bogatyrev, Dynamic Models of Lateritic Bauxite Formation, Geology of Ore Deposits, 545 (2012)

3. M.A.Makarova, V.I.Mamedov, Yu.V. Alekhin, M.I.Makarov, Trace Element Composition of Water in Lateritic Bauxite bearing Mantles of Western Fouta Djalon-Mandingo Province // II All-Russ. Sci. Conf. with Intern. Particip. "Geological Evolution of Water-Rock Interaction", Proceedings, Vladivostok, Dal'nauka (2015)

4. V.I. Mamedov, S.A. Vorob'ev, Ground Air of Bauxite-bearing Lateritic Profile Vestnik MSU. Ser. 4. Geology (2011)

5. V.I. Mamedov, M.A. Makarova, J. Correia Gomes, et. al, Bauxite-bearing Lateritic Mantles of Sangaredi Area, Republic of Guinea International Research Journal, (2016, no. 7 (49)

6. D. Bleackley and D. Phil, Bauxites and Laterites of British Guiana / B.G. Lithographic, Georgetown, BULL. 34 (1964) 